\title{
PENGARUH UKURAN SERBUK TEMPURUNG KELAPA SEBAGAI PENGISI KOMPOSIT POLIESTER TAK JENUH TERHADAP SIFAT MEKANIK DAN PENYERAPAN AIR
}

\author{
Falma Irawati Sijabat, Jenmorisdo Saragih, Halimatuddahliana \\ Departemen Teknik Kimia, Fakultas Teknik, Universitas Sumatera Utara, \\ Jl. Almamater Kampus USU Medan 20155, Indonesia \\ Email : falmairawatisjbt@yahoo.com
}

\begin{abstract}
Abstrak
Serbuk tempurung kelapa (STK) yang berasal dari industri pembuatan obat anti nyamuk dapat digunakan sebagai bahan pengisi (filler) pada komposit. Kajian tentang pemanfaatan STK sebagai pengisi di dalam matriks poliester tak jenuh telah dilakukan dengan tujuan untuk mendapatkan ukuran pengisi STK di dalam komposit poliester tak jenuh dalam menghasilkan sifat mekanik seperti kekuatan tarik (tensile strength), kekuatan bentur (impact strength) dan penyerapan air (water absorption) yang terbaik. Dalam penelitian ini, Poliester tak jenuh dicampur dengan STK dengan ukuran 50, 70 dan 100 mesh dengan perbandingan STK : Poliester tak jenuh 20:80 (berat) menggunakan metoda hand lay-up. Hasil pengujian sifat-sifat mekanik menunjukkan kekuatan tarik maksimum sebesar 42,558 MPa dihasilkan pada komposit dengan ukuran STK 70 mesh. Analisa terhadap sifat kekuatan bentur diperoleh bahwa peningkatan hanya terjadi pada ukuran STK 100 mesh $6083,47 \mathrm{~J} / \mathrm{m}^{2}$. Pada uji daya serap air, penyerapan air yang paling tinggi terjadi pada hari pertama dan STK yang paling banyak menyerap air terdapat pada ukuran STK 70 mesh.
\end{abstract}

Kata kunci : poliester tidak jenuh, serbuk tempurung kelapa, metode hand lay-up

\begin{abstract}
Coconut Shell Powder (CSP) was derived from industrial Making Anti-Mosquito can potentially be used as filler in materials composite. The investigation on the utilization of CSP as filler in a polyester matrix has been done with the purpose to obtain the best CSP fillers size in Unsaturated Polyester (UPR) composites in producing the best mechanical properties such as tensile strength, impact strength and water absorption. In this study, UPR was mixed with CSP at the sizes 50 mesh, 70 mesh and 100 mesh with comparison of CSP: Unsaturated Polyester 20:80 (w/w) by using hand lay-up method. The result of mechanical properties showed that, at a ratio of CSP: PE (20:80), the maximum tensile strength obtained is $42.558 \mathrm{MPa}$ with the size of CSP 70 mesh. The test on impact strength was found that the increasing only occured with the size of CSP 100 mesh at $6083.47 \mathrm{~J} / \mathrm{m}^{2}$. For absorption test, the highest water absorption occured at the first day, water absorption increased with increasing the amount of filler and the most CSP absorbed water at 70 mesh.
\end{abstract}

Keywords: Unsaturated polyester, coconut shell powder, hand lay-up method

\section{Pendahuluan}

Teknologi bahan dewasa ini berkembang dengan pesat. Hal ini didorong oleh kebutuhan akan bahan yang dapat memenuhi karakteristik tertentu yang dikehendaki. Salah satu hasilnya adalah bahan komposit polimer. Kemampuan untuk mudah dibentuk sesuai dengan kebutuhan, baik dalam segi kekuatan, maupun bentuknya dan keunggulannya dalam rasio kekuatan terhadap berat, mendorong penggunaan komposit polimer sebagai bahan pengganti material logam konvensional pada berbagai produk. Penggunaan bahan poliester yang merupakan plastik jenis termoset sebagai matriks pada perkembangan komposit ditujukan karena bahan tersebut mempunyai beberapa kelebihan antara lain : kuat (tidak mudah sobek), tahan terhadap suhu yang tinggi, tidak larut dalam asam organik, penyerapan air yang rendah, dan pengerutan yang minimal bila dibandingkan dengan plastik jenis termoset yang lain [8]. Proses pengerasan resin diberi bahan tambahan yaitu, katalis jenis Methyl Ethyl Keton Peroksida (MEKP), katalis digunakan untuk mempercepat proses pengerasan cairan resin pada suhu yang lebih tinggi. Pemakaian katalis dibatasi sampai $1 \%$ dari volume resin [17]. Sementara itu, tempurung kelapa memiliki sifat daya tahan yang sangat baik, sifat kekasaran yang tinggi dan sifat daya tahan terhadap pengikisan. Komposisi tempurung kelapa seperti selulosa, hemiselulosa dan lignin dapat dilihat pada Tabel 1. Karena sifatsifat yang dimiliki oleh tempurung kelapa ini, 
maka bahan ini sangat baik digunakan untuk jangka waktu yang lama [13]. Beberapa penelitian telah dilakukan dengan memanfaatkan serbuk tempurung kelapa sebagai pengisi pada pembuatan komposit. Salmah,dkk. menggunakan tempurung kelapa sebagai pengisi pada pembuatan komposit termoplastik dengan matriks polietilena. Dari penelitian didapat bahwa penambahan serbuk tempurung kelapa meningkatkan kekuatan tarik dan modulus young tertinggi didapatkan pada saat kandungan serbuk tempurung kelapanya $60 \%$ berat yaitu 12.2 MPa dan 260 MPa [19]. Oleh karena itu, penelitian untuk mendapatkan ukuran serbuk tempurung kelapa yang paling sesuai dan menghasilkan kualitas komposit yang paling baik dibandingkan dengan penelitian sebelumnya perlu dilakukan. Ukuran serbuk tempurung kelapa 50 mesh adalah serbuk yang tertinggal diayakan 70 mesh tetapi lewat dari ayakan 50 mesh, 70 mesh adalah serbuk yang tertinggal diayakan 100 mesh tetapi lewat dari ayakan 70 mesh dan 100 mesh adalah serbuk yang tertinggal diayakan 140 mesh tetapi lewat dari ayakan 100 mesh.

\section{Teori}

Komposit merupakan perpaduan dari dua atau lebih material yang memiliki fasa yang berbeda menjadi suatu material baru yang memiliki properties yang lebih baik dari keduanya. Komposit berguna meningkatkan sifat mekanik dari setiap material yang dipadukan [2]. Adapun kelebihan-kelebihan komposit adalah sebagai berikut [12] :

1. Kekuatannya dapat diatur (tailorability).

2. Tahanan lelah yang baik (fatigue resistance).

3. Tahan korosi.

4. Memiliki kekuatan jenis (rasio kekuatan terhadap berat jenis) yang tinggi.

Tempurung kelapa merupakan salah satu bahan pengisi alamiah yang banyak terdapat di negara - negara tropis seperti Indonesia, Malaysia, Thailand dan Srilangka. Tempurung kelapa merupakan salah satu bagian dari produk pertanian yang memiliki nilai ekonomis tinggi yang dapat dijadikan sebagai basis usaha. Tempurung kelapa juga merupakan senyawa organik sehingga dapat diuraikan oleh mikroorganisme (biodegradasi) secara alamiah di alam, dan juga salah satu sumber bahan pengisi alamiah yang potensial dan mempunyai prospek ekonomis tinggi. Hal ini berkaitan dengan perkembangan teknologi, faktor ekonomis dan isu - isu lingkungan. Komposisi kimia yang dimiliki oleh tempurung kelapa hampir sama dengan komposisi pada batang kayu. Perbedaan yang mendesak adalah pada tempurung kelapa kandungan lignin yang lebih tinggi dan mengandung selulosa yang lebih sedikit dibandingkan dengan batang kayu [13].
Tabel 1. Komposisi Kimia Tempurung Kelapa [7]

\begin{tabular}{|l|c|c|}
\hline \multicolumn{1}{|c|}{ Komponen } & Rumus Kimia & $\begin{array}{c}\text { Persentasi } \\
(\%)\end{array}$ \\
\hline Selulosa & $\left(\mathrm{C}_{6} \mathrm{H}_{10} \mathrm{O}_{5}\right)_{\mathrm{n}}$ & 26,60 \\
\hline Hemiselulosa & $\left(\mathrm{C}_{5} \mathrm{H}_{8} \mathrm{O}_{4}\right)_{\mathrm{n}}$ & 12,34 \\
\hline Lignin & {$\left[\left(\mathrm{C}_{9} \mathrm{H}_{10} \mathrm{O}_{3}\right)\left(\mathrm{CH}_{3} \mathrm{O}\right)\right]_{\mathrm{n}}$} & 29,40 \\
\hline
\end{tabular}

Poliester resin tak jenuh adalah jenis polimer termoset yang memiliki struktur rantai karbon yang panjang. Matriks jenis ini memiliki sifat dapat mengeras pada suhu kamar dengan penambahan katalis tanpa pemberian tekanan ketika proses pembentukannya. Struktur material yang dihasilkan berbentuk crosslink dengan keunggulan pada daya tahan yang lebih baik terhadap jenis pembebanan statik dan impak. Hal ini disebabkan molekul yang dimiliki material ini ialah dalam bentuk rantai molekul raksasa atomatom karbon yang saling berhubungan satu dengan lainnya. Dengan demikian struktur molekulnya menghasilkan efek peredaman yang cukup baik terhadap beban yang diberikan [4].

Gambar 1 menunjukkan reaksi curing poliester tak jenuh. Dalam penelitian ini menggunakan katalis metil etil keton peroksida (MEKP) yang berbentuk cair dan berwarna bening. Semakin banyak katalis yang ditambahkan maka makin cepat pula proses curingnya, tetapi apabila pemberian katalis berlebihan maka akan menghasilkan material yang getas ataupun resin bisa terbakar. Curing ini cukup untuk mereaksikan resin sehingga diperoleh kekuatan dan bentuk plastik yang maksimal sesuai dengan bentuk cetakan yang diinginkan [5].
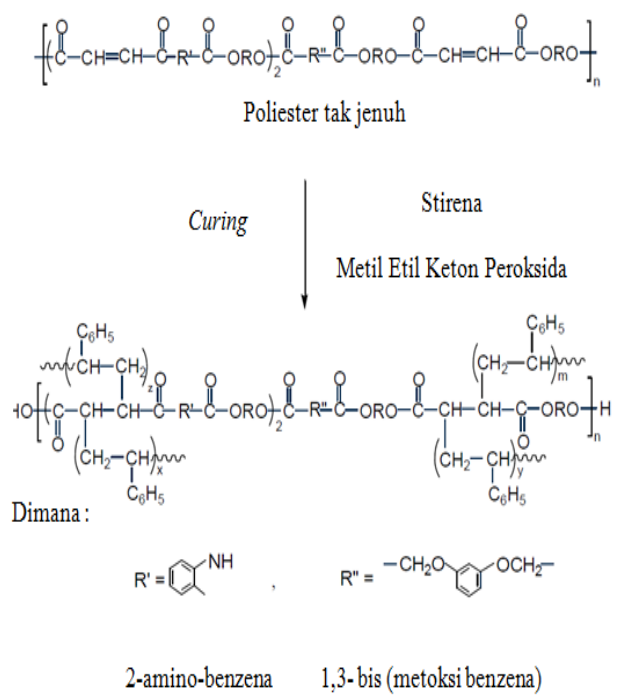

Gambar 1. Reaksi Curing Poliester Tak Jenuh [10] 


\section{Metodologi Penelitia \\ Bahan dan Alat}

Bahan yang digunakan adalah poliester tak jenuh (UPR), serbuk tempurung kelapa (STK) dan metal etil keton peroksida (MEKP) sebagai bahan baku. Alat utama yang digunakan adalah kaca sebagai wadah pembuatan komposit, malam sebagai wadah cetakan komposit, Beaker glass sebagai wadah untuk penyerapan air komposit dan timbangan digital untuk mengukur massa komposit.

\section{Penyediaan Serbuk Tempurung Kelapa}

Serbuk tempurung kelapa yang digunakan diperoleh dari pabrik pembuatan obat anti nyamuk. Serbuk tempurung kelapa kemudian dikeringkan dalam oven dengan suhu $110{ }^{\circ} \mathrm{C}$ selama 5 jam. Tempurung kelapa yang sudah kering, diayak dengan ayakan dengan ukuran 50 mesh, 70 mesh dan 100 mesh.

\section{Persiapan Komposit Poliester Tak Jenuh Berpengisi Serbuk Tempurung Kelapa}

Resin poliester tak jenuh dicampurkan dengan perbandingan pengisi dengan matriks adalah $20: 80$ ( b/b ) ke dalam Beaker glass. Campuran diaduk pelan - pelan hingga merata. Ditambahkan katalis metil etil keton peroksida (MEKP) sebanyak 5 tetes pipet untuk setiap 15,15 gram matriks atau bila dikonversikan dalam fraksi volume katalis yang ditambahkan sebesar 5 tetes pipet untuk setiap 18,41 ml. Campuran diaduk selama 2 menit. Alas cetakan kaca terlebih dahulu diberikan bahan pelicin seperti gliserin ataupun kit mobil agar resin tidak melekat pada cetakan. Dituangkan campuran bahan ke dalam cetakan yang sudah disiapkan dari malam ( lilin ) dan kaca yang telah dibentuk sesuai standar ASTM D 638M-84 M 1. Ratakan permukaan campuran pada cetakan. Tunggu hingga kering selama kurang lebih 24 jam. Komposit yang sudah kering dilepas dari cetakan kemudian bagian dihaluskan bagianbagian permukaannya dengan alat kikir dan amplas [17]. Dilakukan pengujian terhadap komposit yaitu uji kekuatan tarik (tensile strength), uji kekuatan bentur (impact strength), daya serap air (water absorption), fraksi volume serat dalam komposit, dan analisa spektroskopi inframerah (FTIR).

\section{Penyerapan Air}

Komposit UPR-STK yang telah terbentuk dibersih kan dengan tisu. Sebelum pencelupan ke dalam air, komposit terlebih dahulu ditimbang untuk dicatat massa awalnya. Kemudian komposit dicelupkan ke dalam wadah yang berisi air dengan masing-masing wadah memiliki ketinggian air yang sama. Setiap 1 hari komposit diambil dan dibersihkan dengan tisu sampai permukaan komposit betul - betul kering. Komposit yang telah kering ditimbang untuk dicatat penambahan massanya. Prosedur ini dilakukan setiap hari hingga pertambahan massa komposit telah konstan. Selanjutnya dihitung persen daya serap air menggunakan persamaan (1) :

$$
\mathrm{Wg}=\frac{\mathrm{We}-\mathrm{Wo}}{\mathrm{Wo}} \times 100 \%
$$

Dimana :

$\mathrm{Wg}=$ Persentase pertambahan berat komposit

$\mathrm{We}=$ Berat komposit setelah perendaman

$\mathrm{Wo}=$ Berat komposit sebelum perendaman

\section{Perhitungan Densitas Komposit}

Densitas komposit pada matriks dapat dihitung berdasarkan persamaan-persamaan seperti berikut. Masing - masing komposit ditimbang satu per satu menggunakan timbangan digital untuk dicatat massanya $\left(\mathrm{M}_{\mathrm{C}}\right)$. Patahan komposit dimasukan kedalam Beaker glass berisi air dengan volume tertentu. Dengan mengunakan pipet tetes diambil volume air yang merupakan volume komposit dari Beaker glass yang naik. Data - data yang diperoleh kemudian digunakan untuk menghitung densitas komposit dengan menggunakan persamaan (2) [17] :

$\rho c=\frac{M c}{V}$.

Dimana :

$\rho_{\mathrm{C}} \quad=$ Densitas komposit

$\mathrm{M}_{\mathrm{C}}=$ Massa komposit

$\mathrm{V}=$ Volume komposit

\section{Perhitungan Fraksi Volume Serat dalam Komposit}

Bila densitas resin $\left(\rho_{R}\right)$, dan massa resin $\left(\mathrm{M}_{\mathrm{R}}\right)$ telah diketahui maka untuk mencari fraksi volume resin $\left(\mathrm{V}_{\mathrm{R}}\right)$ diberikan dalam persamaan berikut (3) [9] :

$$
\mathrm{V}_{\mathrm{F}}=\frac{\rho_{\mathrm{C}}}{\rho f} \cdot M f
$$

Dimana :

$\mathrm{V}_{\mathrm{F}}=$ Fraksi volume serat $(\mathrm{ml})$

$\rho_{\mathrm{C}}=$ Densitas komposit $(\mathrm{gr} / \mathrm{ml})$

$\rho_{\mathrm{F}} \quad=$ Densitas serat $(\mathrm{gr} / \mathrm{ml})$

$\mathrm{M}_{\mathrm{F}}=$ Massa Serat (gram)

Maka untuk menghitung fraksi massa serat $\left(\mathrm{V}_{\mathrm{F}}\right)$ dan densitas serat $\left(\rho_{\mathrm{F}}\right)$ dihitung berdasarkan persamaan berikut $(4,5)$ [17] :

$$
\begin{aligned}
& V_{F}=1-V_{R} \\
& \rho_{F}=\frac{M_{F}}{M_{C}} \frac{\rho_{C}}{V_{F}}
\end{aligned}
$$


$\mathrm{V}_{\mathrm{F}} \quad=$ Fraksi volume serat

$\mathrm{M}_{\mathrm{F}}=$ Massa serat

$\rho_{\mathrm{F}} \quad=$ Densitas serat

\section{Hasil dan Pembahasan}

Analisa Pengaruh Ukuran Serbuk Tempurung Kelapa Terhadap Kekuatan Tarik (Tensile Strength) Komposit UPR

Dari Gambar 2 dapat dilihat pengaruh penambahan bahan pengisi serbuk tempurung kelapa dengan matriks MEKP terhadap kekuatan tarik komposit.

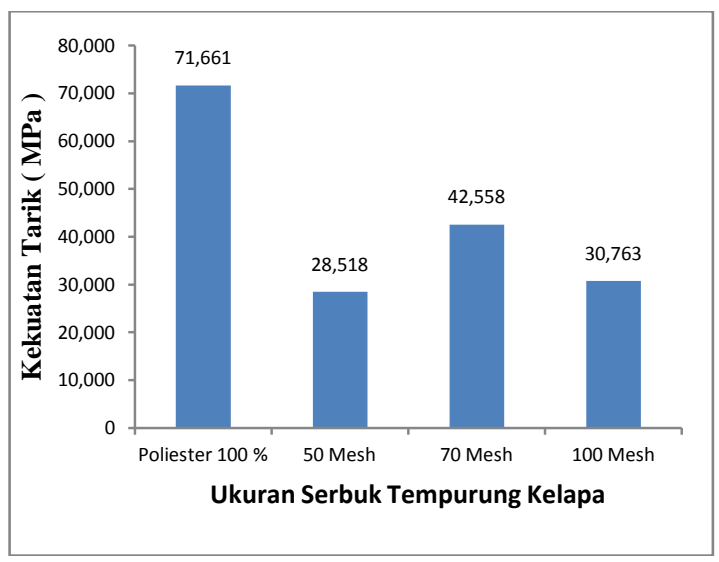

Gambar 2. Pengaruh Ukuran Serbuk Tempurung Kelapa terhadap Kekuatan Tarik Komposit dengan Rasio ( STK : PE) 20 : 80

Nilai kekuatan tarik komposit berada di bawah nilai kekuatan tarik untuk poliester tak jenuh. Hal ini disebabkan ukuran dari STK dapat membuat daerah antar fasa menjadi lemah sehingga kekuatan yang dimiliki bahan komposit untuk menerima tegangan (stress) menurun dan nilai kekuatan tarik komposit berada di bawah matriks murninya. Kekuatan tarik terendah didapat pada saat ukuran STK 50 mesh dan kekuatan tarik tertinggi didapat pada saat ukuran STK 70 mesh. Meningkatnya kekuatan tarik pada komposit dengan pengisi STK 70 mesh disebabkan karena adanya peningkatan ikatan antar muka antara tempurung kelapa dan matriks. Peningkatan ikatan antar muka matriks dan tempurung kelapa sebagai pengisi menghasilkan transisi tekanan yang baik yang akan meningkatkan sifat kekuatan tarik, hal ini juga kemungkinan dikarenakan keseragaman serbuk bahan pengisi dan poliester. Sementara itu, pada komposit ukuran STK 100 mesh, kekuatan tarik kembali menurun. Hal ini disebabkan karena ukuran STK 100 mesh lebih halus, sehingga menyebabkan terjadinya penggumpalan (aglomerasi) STK. Ini disebabkan karena ditinjau dari luas permukaan, dimana ukuran STK 70 mesh memiliki luas permukaan besar, sehingga terjadi reaksi antar muka yang lebih baik dibandingkan dengan ukuran STK 100 mesh.

Hasil yang sama diperoleh oleh Sapuan, dkk. [20] dimana komposit epoksi berisi partikel tempurung kelapa menunjukkan Kekuatan tarik komposit epoksi berisi $16 \%$ partikel tempurung kelapa mengalami peningkatan dibandingkan komposit tanpa pengisi. Hal ini sesuai dengan penelitian yang dilakukan oleh Arif [6], bahwa semakin kecil ukuran STK, maka kekuatan tarik semakin kecil.

\section{Analisa Pengaruh Ukuran Serbuk Tempurung Kelapa Terhadap Pemanjangan pada saat Putus Komposit UPR}

Gambar 3 menunjukkan pengaruh ukuran serbuk tempurung kelapa terhadap pemanjangan pada saat putus (elongation at break) poliester tidak jenuh dan komposit berpengisi STK.

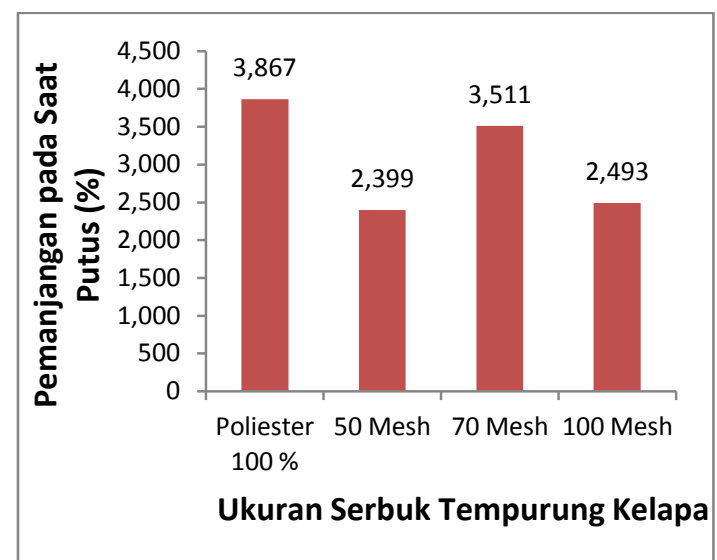

Gambar 3. Pengaruh Ukuran Serbuk Tempurung Kelapa Terhadap Pemanjangan Pada Saat Putus Komposit UPR Berpengisi STK

Nilai pemanjangan pada saat putus yang maksimum berpengisi tersebut berada di bawah nilai pemanjangan pada saat putus untuk poliester tak jenuh. Hal ini disebabkan ukuran dari STK dapat membuat matriks tidak mampu menahan tegangan (stress) yang diberikan sehingga nilai pemanjangan pada saat putus komposit berada dibawah matriks murninya. Pemanjangan pada saat putus yang terendah diperoleh pada ukuran STK 50 mesh yaitu sebesar $2,399 \%$ dan yang tertinggi diperoleh pada ukuran STK 70 mesh yaitu sebesar $3,511 \%$. Sementara itu, pada komposit ukuran STK 100 mesh pemanjangan pada saat putus kembali menurun. Hal ini disebabkan oleh komposit ukuran STK 100 mesh lebih halus, sehingga poliester tak jenuh dan STK tidak terdistribusi secara homogen. Pada partikel ada yang menempel antara partikel yang satu dengan yang lain (aglomerasi), sehingga poliester tak jenuh tidak dapat mengikat partikel secara 
homogeny, Maka poliester tak jenuh mengikat partikel yang saling menempel.

Hal ini juga sesuai dengan penelitian yang dilakukan oleh Ginting [11], bahwa termoplastik bekas dengan pengisi STK (60/40) mengalami penurunan sifat pemanjangan pada saat putus semakin berkurang atau semakin kecil. Hal ini disebabkan STK mengalami penggumpalan (aglomerasi) dan mengeras. Gumpalan (aglomerasi) akan memperkecil luas permukaan dan seterusnya akan melemahkan interaksi di antara pengisi dan matriks sehingga mengakibatkan penurunan sifat fisik bahan polimer.

Analisa Pengaruh Ukuran Serbuk Tempurung Kelapa Terhadap Kekuatan Bentur ( Impact Strength ) Komposit UPR

Gambar 4 menunjukkan pengaruh ukuran serbuk tempurung kelapa terhadap kekuatan bentur komposit.

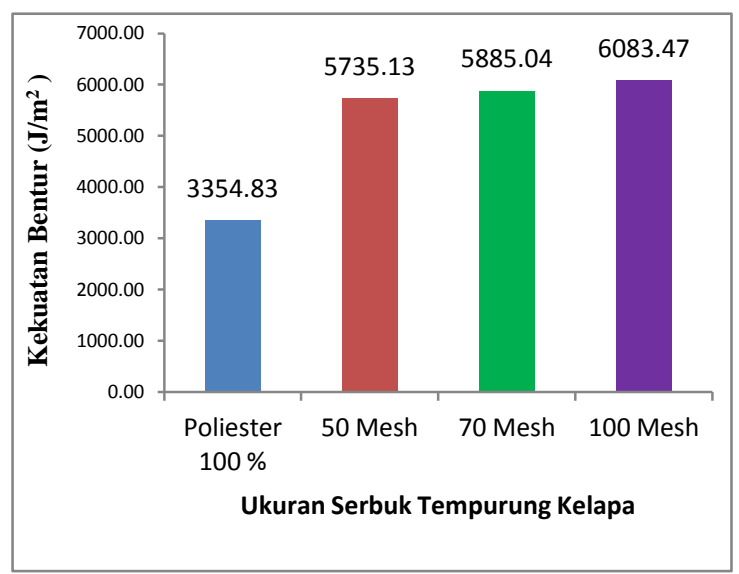

Gambar 4. Pengaruh Ukuran Serbuk Tempurung Kelapa terhadap Kekuatan Bentur Komposit dengan Rasio (STK : PE) 20: 80

Nilai kekuatan bentur komposit berpengisi tersebut berada di atas nilai kekuatan bentur untuk UPR murni yaitu sebesar 3354,83 $\mathrm{J} / \mathrm{m}^{2}$. Peningkatan kekuatan bentur ini disebabkan karena adanya peran pengisi dalam meningkatkan ketahanan bentur dari komposit, dalam hal ini pengisi berperan sebagai pembentuk titik dimana mulainya pematahan (crack formation) dan media pemindahan tegangan (stress transferring medium) [7]. Dalam penelitian ini, kekuatan bentur meningkat karena adanya fleksibilitas jaringan antar fasa yang baik antara matriks dengan pengisi sehingga dengan meningkatnya kandungan bahan pengisi maka bahan komposit akan menyerap energi benturan yang lebih tinggi [15].

\section{Hasil Analisa FTIR Komposit Poliester Berpengisi STK}

Karakteristik FTIR komposit poliester berpengisi serbuk tempurung kelapa dengan ukuran serbuk 70 mesh dan perbandingan pengisi serbuk tempurung kelapa dan poliester adalah 20 : 80 dapat dilihat pada Gambar 5 dibawah ini.

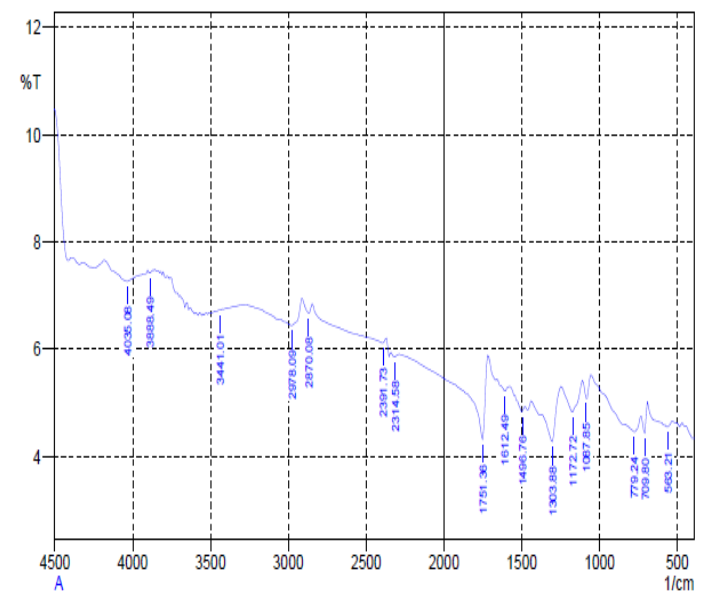

Gambar 5. Grafik Hasil Uji FTIR Komposit dengan perbandingan STK : UPR ( 20: 80 )

Pada Gambar 5 terlihat komposit memiliki gugus fungsi $-\mathrm{OH}$ yang ditandai dengan bilangan gelombang $3441,01 \mathrm{~cm}^{-1}$, gugus ester $(\mathrm{C}=\mathrm{O})$ pada bilangan gelombang $1751,36 \mathrm{~cm}^{-1}$, dan $\mathrm{C}-\mathrm{H}$ pada bilangan gelombang $2978,09 \mathrm{~cm}^{-1}$.

Tabel 2. Hasil data FTIR dari komposit UPR berpengisi STK

\begin{tabular}{|c|c|c|}
\hline No. & $\begin{array}{l}\text { Frekuensi } \\
\text { Vibrasi } \\
\left(\mathrm{cm}^{-1}\right)\end{array}$ & $\begin{array}{l}\text { Ikatan yang Menyerap } \\
\text { Inframerah }\end{array}$ \\
\hline 1 & $3750-3000$ & Regang : O-H, N-H \\
\hline 2 & $3300-3000$ & $\begin{array}{r}\text { Regang C-H : C } \equiv \mathrm{C} \\
\mathrm{H}, \mathrm{C}=\mathrm{C}-\mathrm{H}, \mathrm{Ar}-\mathrm{H}\end{array}$ \\
\hline 3 & $3000-2700$ & $\begin{array}{l}\text { Regang C-H: } \mathrm{CH}_{3}^{-},- \\
\mathrm{CH}^{2}-, \equiv \mathrm{C}-\mathrm{H},-\mathrm{CHO}\end{array}$ \\
\hline 4 & $2400-2100$ & Regang : $\mathrm{C} \equiv \mathrm{C}, \mathrm{C} \equiv \mathrm{N}$ \\
\hline 5 & $1900-1650$ & Regang $: \mathrm{C}=\mathrm{O}$ \\
\hline 6 & $1675-1500$ & Regang: $\mathrm{C}=\mathrm{C}, \mathrm{C}=\mathrm{N}$ \\
\hline 7 & $1200-1000$ & Regang : C-O-C \\
\hline 8 & $1000-650$ & $\begin{array}{l}\text { Tekuk C-H : C=C-H, } \\
\text { Ar-H }\end{array}$ \\
\hline
\end{tabular}

Dari Tabel 2 terlihat bahwa tidak ada puncak gugus baru yang muncul bila dibandingkan dengan karakteristik FTIR poliester tak jenuh dan STK. Ada tiga faktor yang mempengaruhi ikatan yang munculnya gugus baru yakni: penjangkaran mekanik (mechanical anchoring), ikatan kimia antara serat alam dan resin dimana gugus hidroksil $(-\mathrm{OH})$ pada rantai belakang resin (poliester) 
menyediakan sebuah daerah untuk mengadakan ikatan hidrogen terhadap serat alam yang mengandung banyak gugus hidroksil dalam struktur kimianya. dan gaya molekular atraktif (gaya van der Waals dan ikatan hidrogen) [16]. Bila dilihat pada Gambar 5 di atas bahwa hanya terjadi interaksi (ikatan hidrogen) antara gugus hidroksil pada resin dengan gugus hidroksil pada serat alam.

\section{Analisa Pengaruh Ukuran Serbuk Tempurung Kelapa Terhadap Penyerapan Air (Water Absorption) Komposit UPR}

Gambar 6 menunjukkan pengaruh pengisi serbuk tempurung kelapa terhadap penyerapan air bahan komposit yang dihasilkan.

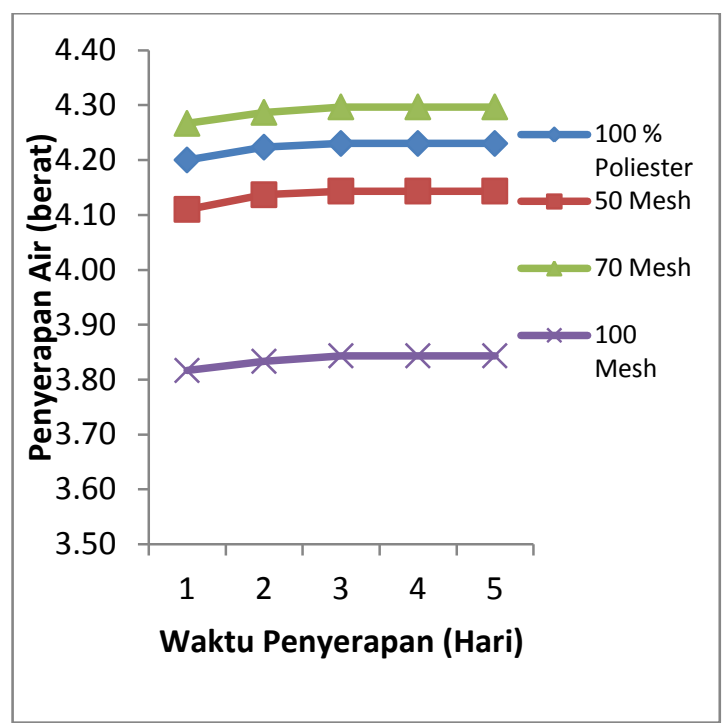

Gambar 6. Pengaruh Ukuran Serbuk Tempurung Kelapa Terhadap Daya Serap Air

Dari Gambar 6 dapat dilihat bahwa penyerapan air bahan komposit akan semakin meningkat dengan penambahan kandungan bahan pengisi. Penyerapan air terbesar terjadi pada hari kedua perendaman, kemudian diikuti pada hari ke 3 dan hari ke 4. Setelah itu, maka penyerapan air bahan komposit terlihat tidak begitu signifikan lagi. Berdasarkan Grafik di atas terlihat bahwa komposit poliester tak jenuh (UPR) berpengisi STK untuk semua komposisi pengisi yang paling banyak menyerap air adalah pada perendaman hari kedua. Komposit yang paling menyerap air terdapat pada ukuran STK 70 mesh. Hal ini disebabkan rendahnya jumlah matriks poliester yang digunakan berimplikasi pada kurang terdistribusinya perekat pada seluruh permukaan serbuk sehingga mengurangi area kontak antar serbuk, area yang tidak terjadi kontak serbuk ini dapat terisi oleh air pada saat perendaman berlangsung [18]. Untuk komposit ukuran STK
100 mesh, paling sedikit menyerap air. Hal ini disebabkan karena ukuran STK yang sangat kecil cenderung menyebabkan terjadi penumpukan serat yang berimplikasi pada tingginya kerapatan komposit, sehingga air sulit untuk diserap oleh komposit. Adapun UPR juga menyerap air pada hari pertama namun setelah itu penyerapan air tidak lagi begitu signifikan. Hal yang menyebabkan matriks UPR masih menyerap air dikarenakan UPR memiliki gugus fungsi ester yang masih mengikat air [21].

Pada umumnya semakin tinggi sifat pengembangan tebal maka semakin tinggi pula sifat daya serap air, dan begitu juga sebaliknya semakin rendah sifat pengembangan tebal komposit maka semakin rendah pula sifat daya serap airnya [1].

\section{Hubungan Ukuran Serbuk Tempurung Kelapa} (STK) Terhadap Pengukuran Fraksi Volume Serat dalam Komposit Poliester Tak Jenuh (UPR)

Tabel 3 menunjukkan pengaruh nilai ukuran STK terhadap fraksi volume serat pada komposit yang dihasilkan.

\section{Tabel 3. Ukuran STK Terhadap Fraksi Volume Serat}

\begin{tabular}{|c|c|}
\hline Ukuran Bahan Pengisi & $\begin{array}{c}\text { Fraksi Volume } \\
\text { Serat }\end{array}$ \\
\hline 50 mesh & 0,1722 \\
\hline 70 mesh & 0,1926 \\
\hline 100 mesh & 0,1851 \\
\hline
\end{tabular}

Berdasarkan Tabel 3 di atas terlihat bahwa semakin banyak serbuk tempurung kelapa yang ditambahkan, maka fraksi volume seratnya semakin besar. Pada setiap sampel komposit dengan volume total yang sama, seiring dengan makin banyaknya serbuk tempurung kelapa yang ditambahkan maka komposit akan semakin ringan dibandingkan dengan poliester murni tanpa penambahan serat. Hal ini disebabkan perbedaan densitas yang cukup besar antara serbuk tempurung kelapa dan poliester. Serbuk tempurung kelapa memiliki densitas $0,65 \mathrm{~kg} / \mathrm{liter}$ [3] sedangkan poliester murni memiliki densitas sebesar 1,21 kg/liter [17]. Maka semakin banyak serbuk tempurung kelapa yang ditambahkan, fraksi volume serat akan semakin besar dan berbanding terbalik dengan menurunnya berat dari komposit.

\section{Kesimpulan}

1. Pengisi serbuk tempurung kelapa belum mampu meningkatkan kekuatan tarik komposit UPR-STK ukuran 70 mesh sebesar 42,558 MPa dari UPR murni yaitu sebesar 71,661 MPa. 
2. Dari hasil analisis sifat pemanjangan pada saat putus komposit, semakin kecil ukuran serbuk tempurung kelapa sifat pemanjangan pada saat putus akan semakin meningkat.

3. Pengisi serbuk tempurung kelapa sudah mampu meningkatkan kekuatan bentur komposit UPR-STK ukuran 100 mesh sebesar $6083,47 \mathrm{~J} / \mathrm{m}^{2}$ dari UPR murni yaitu sebesar $3354,83 \mathrm{~J} / \mathrm{m}^{2}$.

4. Berdasarkan uji serapan air komposit diketahui bahwa daya serap air komposit berpengisi serbuk tempurung kelapa terbesar pada ukuran STK 70 mesh.

5. Semakin banyak serbuk tempurung kelapa yang ditambahkan, maka fraksi volume seratnya semakin besar

\section{Daftar Pustaka}

[1] Abu Bakar, A., Hassan, A., Yusof, A.F.M., "Effect of Accelerated Weathering on the Mechanical Properties of Oil Palm Empty Fruit Bunch Filled UPVC Composites", Iranian Polymer Journal 14 (7): 627-635, 2005.

[2] Anonim, http://www.wikipedia.org/low komposit, Diakses tanggal 10 agustus 2012, 2011.

[3] Anonim, Komposisi Kimia Tempurung Kelapa, www.wikipedia.com, Diakses tanggal 24 April 2012, 2012.

[4] Anonim, Poliester, Jurusan Kimia Raya, Diakses tanggal 24 April 2012, 2012.

[5] Anonim, Metil Etil Keton Peroksida, www.wikipedia.com, Diakses tanggal 24 April 2012, 2001.

[6] Arif, D, “Analissi Pengaruh Ukuran Bahan Pengisi Terhadap Karakteristik Komposit Polipropilena Serbuk Kayu”, Jurnal Universitas Indonesia, Diakses 23 September 2013, 2008.

[7] Cheng, Y.W., Kuwn, Y.C., Phongsakorn, P.T., Dan, M.M.P. dan Saifudin, H.Y., "Tensile Properties and Morphology Study of Polymeric Biocomposite", Faculty of Manufacturing Engineering, Universiti Teknikal Malaysia Melaka, ISSN : 19853157 Vol.3 No.2 Juli-Desember 2009.

[8] Cowd,M.A, Kimia Polimer, terjemahan oleh Firman, H. ITB, Bandung, 1991

[9] Diharjo, K., dan Triyono,T, "Pengetahuan Material Teknik”, Bahan Ajar, Universitas Sebelas Maret, Surakarta, 2003.

[10] Felemban, S.A., Shaaban, A.F., Nahas, N.M., "Synthesis and characterization of some unsaturated polyester resins and their uses as anti chemical varnish coatings", Master Thesis, Umm Al-Qura University, Faculty of
Applied Science, Chemistry Department, Kingdom of Saudi Arabia, 2009.

[11] Ginting,H., Rosdanelli Hasibuan, "Pengaruh Asam stearat terhadap Sifat Kekuatan Tarik dan Pemanjangan pada saat Putus Komposit Termoplastik Bekas Berpengisi Serbuk Tempurung Kelapa", Jurnal Seminar Nasional Teknik Kimia Soebardjo Brotohardjono IX, Surabaya, 2012.

[12] Hakim, Azki, Teknologi Material Komposit, Forum Sains Indonesia, 2007.

[13] Hamid,Tengku Faisal, Pengaruh Modifikasi Kimia terhadap Sifat -Sifat Komposit Polietilena Densitas Rendah ( LDPE) Terisi Tempurung Kelapa, Tesis Program Pascasarjana, Universitas Sumatera Utara: Medan, 2008.

[14] Khalid, M., Ratnam, C.T., Chuah, T.G., Ali, S., Choong, T.S.Y., "Comparative Study Of Polypropylene Composites Reinforced With Oil Palm Empty Fruit Bunch Fiber And Oil Palm Derived Cellulose", Elsevier Materials \& Design 29:173-178, 2006.

[15] Khalil, A.H.P.S., Marliana, M.M., Alshammari, T., "Material Properties of Epoxy-Reinforced Biocomposites With Lignin From Empty Fruit Bunch As Curing Agent”, Bioresources 6(4) : 5206-5223, 2011.

[16] Porwanto, D.A., "Karakterisasi Komposit Berpenguat Serat Bambu dan Serat Gelas Sebagai Alternatif Bahan Baku Industri”, Tugas Akhir, Jurusan Teknik Fisika FTI ITS Surabaya, 2011.

[17] PT. Justus Sakti Raya, Unsaturated Polyester Resin, Jakarta, 1980.

[18] Ray,D.,Rout, J., "Thermoset Biocomposites". Dalam Mohanty, A.K., Misra, M., Drzal, L.T., "Natural Fibers, Biopolymers, And Biocomposites", CRC Press : U.S.A, 2005.

[19] Salmah dkk, Potensi Serbuk Tempurung Kelapa sebagai Pengisi di dalam Komposit Termoplastik, Medan : Lembaga Penelitian Universitas Sumatera Utara, 2008.

[20] Sapuan dkk, Potensi Serbuk Tempurung Kelapa sebagai Pengisi di dalam Komposit Termoset, Medan : Lembaga Penelitian Universitas Sumatera Utara, 2010.

[21] Sutigno, Komposit Papan Partikel, Tesis Magister, Sekolah Pascasarjana, Universitas Sumatera Utara, Medan, 2002. 